\title{
River Breezes for Pollutant Dispersion in GoAmazon2014/5
}

Adan S. S. Medeiros ${ }^{1,2}$, Igor O. Ribeiro ${ }^{1}$, Marcos V. B. Morais ${ }^{4}$, Rita V. Andreoli ${ }^{3}$, Jorge A.

Martins $^{5}$, Leila D. Martins ${ }^{6}$, Carla E. Batista ${ }^{1}$, Patrícia C. Guimarães ${ }^{1}$, Scot T. Martin ${ }^{*}, 7$, Rodrigo A. F. Souza ${ }^{*}, 3$.

${ }^{1}$ Post-graduate Program in Climate and Environment, CLIAMB, INPA/UEA, Av. André Araújo, 2936, 69060001, Manaus, Amazonas, Brazil

${ }^{2}$ Amazonas State University, Center of Superior Studies of Tefé, R. Brasília, 2127, 69470000, Tefé, Amazonas, Brazil

${ }^{3}$ Amazonas State University, Superior School of Technology, Av Darcy Vargas, 1200, 69065020, Manaus, Amazonas, Brazil

${ }^{4}$ Post-graduate Program in Environmental Engineering, Federal University of Technology, Av dos Pioneiros, 3131, 86047-125, Londrina, Paraná, Brazil;

${ }^{5}$ Department of Physics, Federal University of Technology, Av dos Pioneiros, 3131, 86047125, Londrina, Paraná, Brazil;

${ }^{6}$ Department of Chemistry, Federal University of Technology, Av dos Pioneiros, 3131, 86047-125, Londrina, Paraná, Brazil;

${ }^{7}$ School of Engineering and Applied Sciences, Harvard University, 02138, Cambridge, Massachusets, USA

E-mail:scot_martin@harvard.edu,souzaraf@gmail.com

${ }^{*}$ To Whom Correspondence Should be addressed 


\section{Abstract}

The effect of river breezes on pollutant plume dispersion or canalization in the central

3 Amazon was evaluated. A pollution plume changes atmospheric composition downwind of

4 Manaus, a city of 2 million people positioned at the confluence between two wide rivers. Herein,

5 to evaluate the effects of river breezes, two cases were modeled at the mesoscale for March

6 2014. The first case, "with rivers" (wR), simulated the transport and chemistry of the Manaus

7 pollution plume as the rivers were in reality. The second case, "without rivers" (woR), carried out simulations for which all rivers and floodable areas were replaced by forest. The three main conclusions are as follows: (1) Between the two cases, alterations in wind speeds were maximum at local noon, and river breezes influenced horizontal wind fields from surface up to $150 \mathrm{~m}$ in altitude, suggesting a capping height of $150 \mathrm{~m}$ on most days for the influence of river breezes on pollutant concentrations. In agreement with this modeling result, data sets collected at $500 \mathrm{~m}$ by aircraft flights showed no apparent influence of the underlying rivers on plume dispersion. The flights traversed the plume downwind of Manaus during the Observations and Modeling of the Green Ocean Amazon (GoAmazon2014/5) Experiment. (2) Between the wR and wOR cases, changes to downwind concentrations of $\mathrm{O}_{3}, \mathrm{NO}_{x}$, and $\mathrm{CO}$ pollutants were $<6 \%$ as a monthly average at the supersite "T3" of GoAmazon2014/5, which was $70 \mathrm{~km}$ downwind of Manaus and located between the two main rivers. As single events at T3, maximum one-hour concentration differences were $39 \mathrm{ppb}$ for $\mathrm{O}_{3}, 5 \mathrm{ppb}$ for $\mathrm{NO}_{x}$, and $26 \mathrm{ppb}$ for $\mathrm{CO}$. (3) For a focus on the surface layer of the rivers ( 0 to $150 \mathrm{~m}$ in height), river breezes increased the monthly average $\mathrm{O}_{3}, \mathrm{NO}_{x}$, and $\mathrm{CO}$ surface concentrations by $25 \%, 25 \%$, and $<5 \%$, respectively. In addition, strong canalization occurred $5 \%$ of the time based on a difference of $10 \mathrm{ppb}$ in the surface concentrations of at least two of $\mathrm{O}_{3}, \mathrm{NO}_{x}$, and $\mathrm{CO}$ between the wR and wOR cases. In conclusion, although pollutants dispersed by river breezes could at times be a strong effect on observed pollutant concentrations in the surface river boundary layer, overall most pollution was transported at heights well above the effects of the river breezes and moved downwind along the trajectories of the dominant trade winds. 


\section{Introduction}

Amazonia represents the single largest hydrographic basin of water volume on Earth

(Sioli, 1984). Land coverage by rivers constitutes $5 \%$ of the total 7 million square kilometers of

the Amazon basin during dry season, while in the wet season the rivers increase in horizontal

extent by flooding, reaching a surface coverage of $11 \%$ of Amazonia (Hess et al., 2015). An important confluence of wide rivers occurs nearby Manaus, a city of more than 2 million people located at $\left\{3.0^{\circ} \mathrm{S}, 60.0^{\circ} \mathrm{W}\right\}$ in the central Amazon (Figure 1). The Rio Negro ("Black River") flows from the northwest to join the Amazon River, known in Brazil as the Rio Solimões to the west of Manaus and the Rio Amazonas to the east of Manaus. River width around Manaus varies from $2 \mathrm{~km}$ in narrow sections to $20 \mathrm{~km}$ in broader sections.

Wide rivers such as these can induce important atmospheric processes, among which are river breezes (Oliveira and Fitzjarrald, 1993; Dias et al., 2004; dos Santos et al., 2014). River breezes arise from the unequal heating of land and water bodies. In the morning, land heats faster than water, inducing an ascendancy of air over the land and a corresponding subsidence over the river. In this way, surface winds go from the river toward the land. At an altitude of a few hundred meters, the circulation cell is closed, and the winds go from the land to the river, with subsidence over the central portion of the river. The height of the cell depends on the thermal characteristics of the circulation. At night, the opposite behavior occurs (i.e., the cell reverses) because the river cools more rapidly than land.

These river breeze circulations at day and night can be important for the local weather and pollutant dispersion. For instance, during times of weak trade winds Dias et al. (2004) found that river breeze circulation explained the occurrence of clouds on the eastern bank yet an 
absence on the western bank at the confluence between the Amazon and Tapajós rivers, about $600 \mathrm{~km}$ to the east of Manaus. during the Amazon Boundary Layer Experiments (ABLE) (Garstang et al., 1990; Harriss et al., 1990). Based on observations of the meridional component of wind speed, the river breezes were reported as more intense during the dry season than in the wet season, as explained by greater contrast between river and land temperatures given the greater average insolation of the dry season. Simulations further suggested that the river breeze induced by the Rio Negro significantly affected the surrounding daytime surface winds to a distance of $20 \mathrm{~km}$ from the rivers (Oliveira and Fitzjarrald, 1994). The modeled distance was further than initially expected

60 based on earlier modeling studies, and the key difference appeared to be an improved representation of the planetary boundary layer (PBL) in the model. LBA Airborne Regional Experiment-2001 (LBA-CLAIRE-2001), Trebs et al. (2012) traveled by boat to four locations on the Rio Negro and one on the Solimões River. Daily reversals in surface winds were attributed to river breezes. Measurements were made of $\mathrm{NO}, \mathrm{NO}_{2}$, and $\mathrm{O}_{3}$ surface concentrations, and pollution was identified at surface river locations from 10 to $150 \mathrm{~km}$ downwind from Manaus. On at least one day, a reversal in wind direction caused by the afternoon influence of the river breeze was associated with a shift in concentrations representative of background and polluted conditions. Manaus pollution directed by the river breezes appeared to be the explanation. The important data sets of this study were, however, overall sparse (i.e., 8 days of July 2001; Manaus population of 1.2 million at that time), and the recommendation by the authors was therefore to implement long-term monitoring stations 

the dispersion of the Manaus pollution plume. (GoAmazon2014/5) Experiment was carried out to study the effects of pollutant outflow from Manaus on atmospheric chemistry, regional climate, and terrestrial ecosystems of an otherwise typically clean background environment (Martin et al., 2016). Under fair-weather conditions, the pollution plume was carried westward by equatorial trade winds (Kuhn et al., 2010; Martin et al., 2017). The GoAmazon2014/5 terrestrial supersite, called "T3", was $70 \mathrm{~km}$ to the west of Manaus (Figure 1).

An important question for the GoAmazon2014/5 experiment was to what extent river breezes might disperse or canalize Manaus pollution, thereby possibly influencing the interpretation of data sets collected at the $\mathrm{T} 3$ supersite. For a limiting case of full river canalization, no pollution would reach the T3 site. For an opposite limiting case of weak or no river breeze effects, all pollution would follow the stable trade winds when fair-weather conditions prevailed, and air parcels sampled at the $\mathrm{T} 3$ site would be interpreted in a fully Lagrangian framework downwind of the Manaus source region. Between these limiting cases, partial dispersion of the Manaus pollution plume would be possible. In the context of these possibilities and in light of the work of Oliveira and Fitzjarrald $(1993,1994)$ and Trebs et al.

91 (2012), the study herein presents an analysis of how the rivers around Manaus affect downwind

92 pollutant dispersion or canalization. The analysis uses mesoscale WRF-Chem modeling and 


\section{Simulations}

95

96

\subsection{Model Description}

6

The Weather Research and Forecast model coupled with Chemistry (WRF-Chem) is described by Grell et al. (2005). Version 3.6.1 was used for the present study. A two-domain configuration was used (Medeiros et al., 2017). The inner domain represented an area of $302 \mathrm{~km}$ $\times 232 \mathrm{~km}$, had a horizontal resolution of $2 \mathrm{~km} \times 2 \mathrm{~km}$, and had 38 vertical layers from ground to $160 \mathrm{hPa}$. The outside boundaries of the inner domain were forced by data from an outer domain. The outer domain represented an area of $1050 \mathrm{~km} \times 800 \mathrm{~km}$, had a resolution of $10 \mathrm{~km} \times 10 \mathrm{~km}$, and had 38 vertical layers from ground to $160 \mathrm{hPa}$. Both domains were centered on $\left\{2.908^{\circ} \mathrm{S}\right.$, $\left.60.319^{\circ} \mathrm{W}\right\}$. The meteorology of the outside boundary of the outer domain was forced by the Climate Forecast System Reanalysis (CFSv2) product of the National Center for Environment Prediction (NCEP) at a temporal resolution of $6 \mathrm{~h}$ and a spatial resolution of $0.5^{\circ}$ (Saha et al., 2011). The inputs of surface temperature were also considered based on CFSv2 product. The chemical composition of the outside boundary of the outer domain was forced by the Model for Ozone and Related chemical Tracers (MOZART-4) (Emmons et al., 2010).

Data of the Moderate Resolution Imaging Spectroradiometer (MODIS) satellite at a resolution of $500 \mathrm{~m}$ were used for land cover (Channan et al., 2014). These data were used as obtained for the case of "with rivers" (wR). For the case of "without rivers" (woR), the rivers and main flooded areas of MODIS land cover were replaced by forest in the pre-processor of the WRF-Chem model.

4 The physics parametrizations used in the simulations were described previously (Ying et al., 2009; Misenis and Zhang, 2010; Gupta and Mohan, 2015), including for the study region in the central Amazon (Medeiros et al., 2017). The parametrizations treated the physics of the 

et al., 2006), shortwave radiation (Chou and Suarez, 1999), longwave radiation (Mlawer et al., 1997), cloud microphysics (Lin et al., 1983), and cumulus clouds (Grell and Freitas, 2014). At Figure S1, the comparison between observed and simulated temperature, relative humidity and wind speed at "T3" supersite show that the simulations performed herein represent the diurnal cycle of these variables. Nature (MEGAN, version 2.1) (Guenther et al., 2012) was used for biogenic emissions. Anthropogenic emissions from transport, power, and industry for Manaus in 2014 were based on the emission inventory of Medeiros et al. (2017). The Regional Acid Deposition Model (RADM2) was used to simulate gas-phase chemistry (Chang et al., 1989).

\subsection{Model Runs} characteristics between the two simulations remained the same. This approach aimed to isolate the river breeze effects on the transport of pollutants downwind of Manaus. For time zero, the inner and outer domains were both initialized to CFSv2 and MOZART-4. A spin-up time of $24 \mathrm{~h}$

133 was used, which was sufficient to fully replace the air of the inner domain. After the spin-up period, simulations in lots of $72 \mathrm{~h}$ were performed for March 2014 as a balance between conserving computing resources and avoiding excessive numerical drift (Medeiros et al., 2017).

\section{3. Data Sets}


2017). Concentrations of $\mathrm{O}_{3}$ (Thermo Scientific Model 49i), $\mathrm{NO}_{x}$ (airborne $\mathrm{NO}_{x}$ analyzer, Air Quality Devices), and CO (Los Gatos 23r) were measured. The aircraft performed 16 flights during IOP1. Data sets of two flights (March 14 and 21) were chosen for analysis herein based on flight tracks over both river and land while cutting across the Manaus pollution plume at an altitude of approximately $500 \mathrm{~m}$. There were no flights at lower altitude.

\section{Results and Discussion}

\subsection{Height of River Breeze Circulation Cell}

The effect of river breezes on horizontal wind speeds was evaluated. As monthly means, the left column of Figure 2 presents the wR case, and the right column shows the differences between the wR and woR cases. The rows represent plots at surface, 100-m altitude, and 500-m altitude. Comparison between columns shows that the river breezes significantly affected mean surface wind speeds but that the effects decreased with altitude.

The change of horizontal wind speeds with altitude is presented in detail in Figure 3 through height cross sections along points A, B, and C above the Rio Negro nearby Manaus (cf. Figure 1). Panels in Figure 3 show wind speed differences between the wR and woR cases for all times as well as for 00:00, 06:00, 12:00, and 18:00 (local time). In the absence of solar radiation (i.e., at 00:00 and 18:00 local), the differences in horizontal wind speeds were relatively small. The strongest differences were at noon corresponding to maximum daily solar irradiance, as expected, because of the largest thermal gradients between land and river at these times (Oliveira and Fitzjarrald, 1993, 1994; Dias et al., 2004; Fitzjarrald et al., 2008; de Souza and dos Santos Alvalá, 2014; dos Santos et al., 2014; de Souza et al., 2016). The river breeze effect was confined to less than $150 \mathrm{~m}$, as shown in the monthly average plot of Figure 3. Across individual days, the maximum and minimum heights for significant noontime river breeze effects were 300 
and $60 \mathrm{~m}$, respectively (results not shown). Overall, the results of Figures 2 and 3 lead to the conclusion that the river breeze effect on wind speeds was confined on most days to below 150 $m$ in altitude, even under high noontime solar irradiance.

For comparison, aircraft data sets of $\mathrm{O}_{3}, \mathrm{NO}_{x}$, and $\mathrm{CO}$ concentrations from 500-m altitude are plotted in Figure 4 (Martin et al., 2017). Carbon monoxide was mostly inert on the time scales of the simulations, oxides of nitrogen were significantly lost during downwind transport, and ozone was a secondary pollutant rapidly produced within Manaus and over the nearby rivers, quickly reaching steady-state concentrations (Medeiros et al., 2017; Rafee et al., 2017). The panels of the left column of Figure 4 show that the flight paths intercepted the Manaus pollution plume in the planetary boundary layer on March 14 from 10:20 to 11:20 (local time; UTC - 4 h). The panels of the right column show that interception took place on March 21 from 13:00 to 14:00. Below each map, concentrations along the flight tracks are plotted, and the red shading represents times that the aircraft was over a river. The results show that there was no obvious influence of river breezes on the dispersion of the Manaus pollutant plume at $500 \mathrm{~m}$. Although Figure 4 shows only two flights, which were selected for substantial data coverage over both river and land during a single flight, all 16 flights from March 2014 were investigated, and a strong river breeze effect was not apparent in any of them (analysis not shown). The aircraft data sets thus corroborate the tendencies represented in Figures 2 and 3 that the effects of rivers presence on plume dispersion are confined to the surface boundary layer over the rivers, typically below $150 \mathrm{~m}$.

\subsection{Effects of River Breezes on Downwind Concentrations}

The "T3" GoAmazon2014/5 terrestrial supersite was located at $\{-3.2133 \mathrm{~N},-60.5987 \mathrm{E}\}$, approximately $70 \mathrm{~km}$ to the west of Manaus and in the dominant direction of prevailing trade 

blue line, the woR case as the red line, and their difference as the black line. The pollutant concentrations did not change greatly in the presence or absence of the rivers. Quantitatively, the perturbations caused by the presence of the rivers on the $\mathrm{O}_{3}, \mathrm{NO}_{x}$, and $\mathrm{CO}$ concentrations were less than $6 \%$. Maximum one-hour concentration differences were $39 \mathrm{ppb}$ for $\mathrm{O}_{3}, 5 \mathrm{ppb}$ for $\mathrm{NO}_{x}$, and $26 \mathrm{ppb}$ for $\mathrm{CO}$ across the month. The overall implication is that the effects of the trade winds on transport largely dominated over the influence of river breezes in this region when considering the larger part of Manaus pollutant outflow, in agreement with the modeling and observational results of section 4.1 .

\subsection{Surface River Concentrations}

Two locations "R1" and "R2" were chosen to evaluate pollutant dispersion and canalization in the river surface layer ( 0 to $150 \mathrm{~m}$ ). Based on the prevailing trade winds location R1 at $\{-3.0699 \mathrm{~N},-60.2199 \mathrm{E}\}$ consistently intercepted the urban outflow (Figure 1). By the trade winds that passed over and then downwind of Manaus. For the analysis, the simulated pollutant concentrations at $\mathrm{R} 2$ were compared to those at $\mathrm{R} 1$ in the $\mathrm{wR}$ and woR cases to test the extent of river canalization of the plume, meaning transport of air parcels along the river rather than in the prevailing direction of the synoptic-scale trade winds. 

river breezes thus shifted the surface level dispersion pattern of the Manaus plume. At both sites, the differences were smaller $(<5 \%)$ for $\mathrm{CO}$ concentrations because regional background concentrations exceeded the Manaus contribution. Absolute changes $( \pm \mathrm{ppb})$ for four time periods across the day are listed in Table S1 of the Supplementary Material. The difference between the $w R$ and woR cases exceeded $10 \mathrm{ppb}$ at $\mathrm{R} 2$, which can be called strong canalization, for at least two pollutants at 5\% frequency for March 2014.

An example of strong canalization occurred for the simulation on March 2 at 13:00 (local time). The three columns of Figure 8 show the wR case, the woR case, and their difference, all at surface altitude. The three rows show results for $\mathrm{O}_{3}, \mathrm{NO}_{x}$, and $\mathrm{CO}$. For the wR case, a small portion of the pollution plume traversed the course of Rio Negro to the northwest, following the local wind field. A boat collecting surface samples would report increases of $\mathrm{O}_{3}$ by $20 \mathrm{ppb}$ and of CO by $10 \mathrm{ppb}$. Overall, comparison of the wR and woR case shows that the simulated plume was tighter with less transverse spreading in the absence of rivers. In both the wR and woR cases, most pollution followed the predominant direction of the trade winds, and the effects of river canalization on diverting the plume were small by comparison. dispersion or canalization in the central Amazon. The simulations showed that the horizontal monthly mean wind speeds were significantly altered by river breezes to altitudes of $75 \mathrm{~m}$ as monthly 24-h means and to $150 \mathrm{~m}$ for monthly averages across the maximum noontime solar radiation. The strongest effects of river breezes on pollutant dispersion were thus from 0 to 150 $m$ above the river surface. Aircraft data confirmed the absence of observable effects of river breezes on plume dispersion at flight level $(500 \mathrm{~m})$. Overall, the perturbation on pollutant 

average $\mathrm{O}_{3}, \mathrm{NO}_{x}$, and $\mathrm{CO}$ surface concentrations increased by $25 \%, 25 \%$, and $<5 \%$, respectively. frequency of 5\% for March 2014. The overall conclusion is that the Manaus pollution plume dispersion could at times be partially canalized leading to significant changes of surface river concentrations even as most pollution passed overhead of the river circulation cell and dominantly followed trajectories along the prevailing overhead trade winds.

\section{Acknowledgments}

We acknowledge support from the Central Office of the Large-Scale Biosphere-Atmosphere Experiment in Amazonia (LBA), the National Institute of Amazonian Research (INPA), the Amazonas State University (UEA), the Brazilian Innovation Agency (FINEP), and the Atmospheric System Research (ASR) program of the Office of Biological and Environmental Research, Office of Science, United States Department of Energy (DOE) (grant DESC0011115). A. Medeiros thanks the Brazilian Federal Agency for Support and Evaluation of Graduate Education (CAPES) for the grant scholarship, linked to the doctoral program in

Climate and Environment (CLIAMB). Funding was received under grant 062.00568/2014 of the Amazonas State Research Foundation (FAPEAM). A FAPEAM grant of a Senior International Visiting Researcher is also acknowledged. The work was conducted under scientific licenses 001030/2012-4 and 400063/2014-0 of the Brazilian National Council for Scientific and Technological Development (CNPq). 


\section{References}

Chang, J., Middleton, P., Stockwell, W., Binkowski, F., and Byun, D.: The regional acid deposition model and engineering model, State-of-Science/Technology, National Acid Precipitation Assessment Program, 1989.

Channan, S., Collins, K., and Emanuel, W.: Global mosaics of the standard MODIS land cover type data, University of Maryland and the Pacific Northwest National Laboratory, College Park, Maryland, USA, 30, 2014.

Chen, F., Janjić, Z., and Mitchell, K.: Impact of Atmospheric Surface-layer Parameterizations in the new Land-surface Scheme of the NCEP Mesoscale Eta Model, Bound.-Layer Meteorol., 85, 391-421, 10.1023/a:1000531001463, 1997.

Chou, M.-D., and Suarez, M. J.: A solar radiation parameterization for atmospheric studies, NASA Tech. Memo, 104606, 40, 1999.

de Souza, D. O., and dos Santos Alvalá, R. C.: Observational evidence of the urban heat island of Manaus City, Brazil, Meteorological Applications, 21, 186-193, 10.1002/met.1340, 2014.

de Souza, D. O., dos Santos Alvalá, R. C., and do Nascimento, M. G.: Urbanization effects on the microclimate of Manaus: A modeling study, Atmospheric Research, 167, 237-248, 2016.

Dias, M. S., Dias, P. S., Longo, M., Fitzjarrald, D. R., and Denning, A. S.: River breeze circulation in eastern Amazonia: observations and modelling results, Theor. Appl. Climatol., 78, 111-121, 10.1007/s00704-004-0047-6, 2004.

dos Santos, M. J., Silva Dias, M. A. F., and Freitas, E. D.: Influence of local circulations on wind, moisture, and precipitation close to Manaus City, Amazon Region, Brazil, Journal of Geophysical Research: Atmospheres, 119, 13,233-213,249, 10.1002/2014jd021969, 2014.

Emmons, L., Walters, S., Hess, P., Lamarque, J.-F., Pfister, G., Fillmore, D., Granier, C., Guenther, A., Kinnison, D., and Laepple, T.: Description and evaluation of the Model for Ozone and Related chemical Tracers, version 4 (MOZART-4), Geosci. Model Dev., 3, 4367, 10.5194/gmd-3-43-2010, 2010. 
Fitzjarrald, D. R., Sakai, R. K., Moraes, O. L., Cosme de Oliveira, R., Acevedo, O. C., Czikowsky, M. J., and Beldini, T.: Spatial and temporal rainfall variability near the Amazon-Tapajós confluence, J. Geophys. Res., 113, n. G1, 10.1029/2007JG000596, 2008.

Garstang, M., Greco, S., Scala, J., Swap, R., Ulanski, S., Fitzjarrald, D., Martin, D., Browell, E., Shipman, M., and Connors, V.: The Amazon boundary-layer experiment (ABLE 2B): A meteorological perspective, Bull. Am. Meteorol. Soc., 71, 19-32, 10.1175/15200477(1990)071<0019:TABLEA>2.0.CO;2, 1990.

Grell, G. A., Devenyi, J., Dudhia, J., and Stauffer, D. R.: A description of the fifth-generation Penn State/NCAR mesoscale model (MM5). NCAR Tech. Note NCAR/TN-398STR., 1994.

Grell, G. A., Peckham, S. E., Schmitz, R., McKeen, S. A., Frost, G., Skamarock, W. C., and Eder, B.: Fully coupled "online” chemistry within the WRF model, Atmos. Environ., 39, 6957-6975, 10.1016/j.atmosenv.2005.04.027, 2005.

Grell, G. A., and Freitas, S. R.: A scale and aerosol aware stochastic convective parameterization for weather and air quality modeling, Atmos. Chem. Phys., 14, 5233-5250, 10.5194/acp14-5233-2014, 2014.

Guenther, A. B., Jiang, X., Heald, C. L., Sakulyanontvittaya, T., Duhl, T., Emmons, L. K., and Wang, X.: The Model of Emissions of Gases and Aerosols from Nature version 2.1 (MEGAN2.1): an extended and updated framework for modeling biogenic emissions, Geosci. Model Dev., 5, 1471-1492, 10.5194/gmd-5-1471-2012, 2012.

Gupta, M., and Mohan, M.: Validation of WRF/Chem model and sensitivity of chemical mechanisms to ozone simulation over megacity Delhi, Atmos. Environ., 122, 220-229, 10.1016/j.atmosenv.2015.09.039, 2015.

Harriss, R., Garstang, M., Wofsy, S., Beck, S., Bendura, R., Coelho, J., Drewry, J., Hoell, J., Matson, P., and McNeal, R. J.: The Amazon boundary layer experiment: wet season 1987, J. Geophys. Res., 95, n. D10, 16721-16736, 10.1029/JD095iD10p16721, 1990.

Hong, S.-Y., Noh, Y., and Dudhia, J.: A new vertical diffusion package with an explicit treatment of entrainment processes, Mon. Weather Rev., 134, 2318-2341, 10.1175/MWR3199.1, 2006. 
Kuhn, U., Ganzeveld, L., Thielmann, A., Dindorf, T., Schebeske, G., Welling, M., Sciare, J., Roberts, G., Meixner, F. X., Kesselmeier, J., Lelieveld, J., Kolle, O., Ciccioli, P., Lloyd, J., Trentmann, J., Artaxo, P., and Andreae, M. O.: Impact of Manaus City on the Amazon Green Ocean atmosphere: ozone production, precursor sensitivity and aerosol load, Atmos. Chem. Phys., 10, 9251-9282, 10.5194/acp-10-9251-2010, 2010.

Lin, Y.-L., Farley, R. D., and Orville, H. D.: Bulk parameterization of the snow field in a cloud model, J. Clim. Appl. Meteorol., 22, 1065-1092, 10.1175/1520-

0450(1983)022<1065:BPOTSF>2.0.CO;2, 1983.

Martin, S. T., Artaxo, P., Machado, L. A. T., Manzi, A. O., Souza, R. A. F., Schumacher, C., Wang, J., Andreae, M. O., Barbosa, H. M. J., Fan, J., Fisch, G., Goldstein, A. H., Guenther, A., Jimenez, J. L., Pöschl, U., Silva Dias, M. A., Smith, J. N., and Wendisch, M.:

Introduction: Observations and Modeling of the Green Ocean Amazon

(GoAmazon2014/5), Atmos. Chem. Phys., 16, 4785-4797, 10.5194/acp-16-4785-2016, 2016.

Martin, S. T., Artaxo, P., Machado, L., Manzi, A. O., Souza, R. A. F., Schumacher, C., Wang, J., Biscaro, T., Brito, J., Calheiros, A., Jardine, K., Medeiros, A., Portela, B., Sá, S. S. d., Adachi, K., Aiken, A. C., Albrecht, R., Alexander, L., Andreae, M. O., Barbosa, H. M. J., Buseck, P., Chand, D., Comstock, J. M., Day, D. A., Dubey, M., Fan, J., Fast, J., Fisch, G., Fortner, E., Giangrande, S., Gilles, M., Goldstein, A. H., Guenther, A., Hubbe, J., Jensen, M., Jimenez, J. L., Keutsch, F. N., Kim, S., Kuang, C., Laskin, A., McKinney, K., Mei, F., Miller, M., Nascimento, R., Pauliquevis, T., Pekour, M., Peres, J., Petäjä, T., Pöhlker, C., Pöschl, U., Rizzo, L., Schmid, B., Shilling, J. E., Dias, M. A. S., Smith, J. N., Tomlinson, J. M., Tóta, J., and Wendisch, M.: The Green Ocean Amazon Experiment (GoAmazon2014/5) Observes Pollution Affecting Gases, Aerosols, Clouds, and Rainfall over the Rain Forest, Bull. Am. Meteorol. Soc., 98, 981-997, 10.1175/bams-d-15-00221.1, 2017.

Medeiros, A. S. S., Calderaro, G., Guimarães, P. C., Magalhaes, M. R., Morais, M. V. B., Rafee, S. A. A., Ribeiro, I. O., Andreoli, R. V., Martins, J. A., Martins, L. D., Martin, S. T., and Souza, R. A. F.: Power plant fuel switching and air quality in a tropical, forested environment, Atmos. Chem. Phys., 17, 8987-8998, 10.5194/acp-17-8987-2017, 2017. 
Misenis, C., and Zhang, Y.: An examination of sensitivity of WRF/Chem predictions to physical parameterizations, horizontal grid spacing, and nesting options, Atmos. Res., 97, 315-334, 10.1016/j.atmosres.2010.04.005, 2010.

Mlawer, E. J., Taubman, S. J., Brown, P. D., Iacono, M. J., and Clough, S. A.: Radiative transfer for inhomogeneous atmospheres: RRTM, a validated correlated-k model for the longwave, J. Geophys. Res., 102, n. D14, 16663-16682, 10.1029/97JD00237, 1997.

Oliveira, A. P., and Fitzjarrald, D. R.: The Amazon river breeze and the local boundary layer: I. Observations, Bound.-Layer Meteorol., 63, 141-162, 10.1007/BF00705380, 1993.

Oliveira, A. P., and Fitzjarrald, D. R.: The Amazon river breeze and the local boundary layer: II. Linear analysis and modelling, Bound.-Layer Meteorol., 67, 75-96, 10.1007/BF00705508, 1994.

Rafee, S. A. A., Martins, L. D., Kawashima, A. B., Almeida, D. S., Morais, M. V., Souza, R. V., Oliveira, M. B., Souza, R. A., Medeiros, A. S., and Urbina, V.: Contributions of mobile, stationary and biogenic sources to air pollution in the Amazon rainforest: a numerical study with the WRF-Chem model, Atmos. Chem. Phys., 17, 7977-7995, 10.5194/acp-17-7977$2017,2017$.

Saha, S., Moorthi, S., Wu, X., Wang, J., Nadiga, S., Tripp, P., Behringer, D., Hou, Y.-T., Chuang, H.-y., Iredell, M., Ek, M., Meng, J., Yang, R., Mendez, M. P., van den Dool, H., Zhang, Q., Wang, W., Chen, M., and Becker, E.: NCEP Climate Forecast System Version 2 (CFSv2) 6-hourly Products, in, Research Data Archive at the National Center for Atmospheric Research, Computational and Information Systems Laboratory, Boulder, CO, 2011.

Schmid, B., Tomlinson, J. M., Hubbe, J. M., Comstock, J. M., Mei, F., Chand, D., Pekour, M. S., Kluzek, C. D., Andrews, E., Biraud, S. C., and McFarquhar, G. M.: The DOE ARM Aerial Facility, Bull. Am. Meteorol. Soc., 95, 723-742, 10.1175/bams-d-13-00040.1, 2014.

Sioli, H.: The Amazon and its main affluents: hydrography, morphology of the river courses, and river types, in: The Amazon, Springer, 127-165, 1984.

Trebs, I., Mayol-Bracero, O. L., Pauliquevis, T., Kuhn, U., Sander, R., Ganzeveld, L., Meixner, F. X., Kesselmeier, J., Artaxo, P., and Andreae, M. O.: Impact of the Manaus urban plume 
Atmos. Chem. Phys. Discuss., https://doi.org/10.5194/acp-2018-347

Manuscript under review for journal Atmos. Chem. Phys.

Discussion started: 23 April 2018

(c) Author(s) 2018. CC BY 4.0 License.

(c) (1)

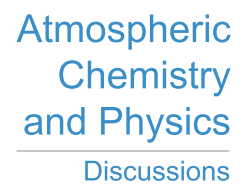

on trace gas mixing ratios near the surface in the Amazon Basin: Implications for the NONO2-O3 photostationary state and peroxy radical levels, J. Geophys. Res., 117, n. D5, 10.1029/2011JD016386, 2012.

Ying, Z., Tie, X., and Li, G.: Sensitivity of ozone concentrations to diurnal variations of surface emissions in Mexico City: A WRF/Chem modeling study, Atmos. Environ., 43, 851-859, 10.1016/j.atmosenv.2008.10.044, 2009. 


\section{List of Figures}

Figure 1. Satellite image of the Manaus region. The Rio Negro comes from the northwest, and the Rio Solimões arrives from the west. The confluence of the two rivers is to the southeast of Manaus, beginning the Amazon River ("Rio Amazonas”). Yellow markers show locations of (i) the measurement supersite called "T3", (ii) two river locations "R1" and "R2" considered in the modeling methodology herein, and (iii) points "A", "B", and "C" along a river cross section, also used in the methodology herein.

Figure 2. Mean horizontal wind speeds for March 2014. The left column represents the base case wR ("with rivers"). The right column represents the difference case (wR - woR) ("with rivers compared to without rivers"). Rows represent altitude as (1) near surface, (2) $100 \mathrm{~m}$, and (3) $500 \mathrm{~m}$.

Figure 3. Difference in mean horizontal wind speed for (wR - woR) ("with rivers compared to without rivers"). Plots are shown as vertical cross sections along points $\mathrm{A}, \mathrm{B}$, and $\mathrm{C}$ of the Figure 1 as follows: (a) for all of March 2014, (b) at 00:00, (c) at 06:00, (d) at 12:00, and (e) at 18:00, all in local time (UTC - $4 \mathrm{~h}$ ).

Figure 4. Concentrations of $\mathrm{O}_{3}, \mathrm{NO}_{x}$, and $\mathrm{CO}$ measured by instrumentation on board an aircraft during GoAmazon2014/5 at an altitude of approximately $500 \mathrm{~m}$ (Martin et al., 2017). Concentrations are plotted in false color, and the legends on the right-hand side of each row show the scaling. Below each main panel, a line plot shows the concentrations marked by points A through $\mathrm{H}$ along the flight paths. Red shading demarcates periods when the aircraft was flying over a river.

Figure 5. Time series of $\mathrm{O}_{3}$ concentrations at the T3, R1, and $\mathrm{R} 2$ locations. The left column plots 
the cases of wR ("with rivers"; blue) and woR ("without rivers"; red). The right column shows the difference in concentrations as (wR - woR).

Figure 6. Time series of $\mathrm{NO}_{x}$ concentrations at the $\mathrm{T} 3, \mathrm{R} 1$, and $\mathrm{R} 2$ locations. The left column plots the cases of wR ("with rivers"; blue) and woR ("without rivers"; red). The right column shows the difference in concentrations as (wR - woR).

Figure 7. Time series of $\mathrm{CO}$ concentrations at the T3, R1, and R2 locations. The left column plots the cases of wR ("with rivers"; blue) and woR ("without rivers"; red). The right column shows the difference in concentrations as (wR - woR).

Figure 8. Near-surface concentrations of (a) $\mathrm{O}_{3}$, (b) $\mathrm{NO}_{x}$, and (c) $\mathrm{CO}$ (March 2, 13:00 local time, UTC - 4 h). The first and second columns represent the cases of wR ("with rivers") and woR ("without rivers"), respectively. The vector field in each panel shows the near-surface horizontal winds. The third column shows the difference in concentrations as (wR - woR). For reference, the locations of T3, R1, and R2 are marked. 
Atmos. Chem. Phys. Discuss., https://doi.org/10.5194/acp-2018-347

Manuscript under review for journal Atmos. Chem. Phys.

Discussion started: 23 April 2018

(c) Author(s) 2018. CC BY 4.0 License.

(c) (1)

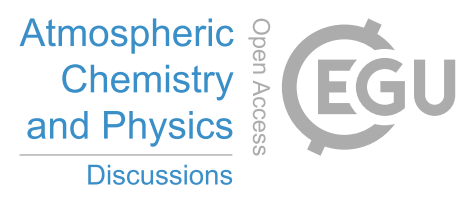

Table 1. Percent change in pollutant concentration $X$ for the case of wR ("with rivers")

compared to that of woR ("without rivers"), calculated as $\left(X_{\mathrm{wR}}-X_{\mathrm{woR}}\right) / X_{\mathrm{wR}}$, where $X$ is

the monthly mean at a location $\mathrm{T} 3, \mathrm{R} 1$, or $\mathrm{R} 2$ for each of $\mathrm{O}_{3}, \mathrm{NO}_{x}$, and $\mathrm{CO}$.

\begin{tabular}{cccc}
\hline & $\mathrm{O}_{3}$ & $\mathrm{NO}_{x}$ & $\mathrm{CO}$ \\
\hline $\mathrm{T} 3$ & $+5.5 \%$ & $-4.6 \%$ & $+1.2 \%$ \\
$\mathrm{R} 1$ & $+28.4 \%$ & $+26.0 \%$ & $+2.9 \%$ \\
$\mathrm{R} 2$ & $+25.5 \%$ & $+25.6 \%$ & $+2.6 \%$ \\
\hline
\end{tabular}


Atmos. Chem. Phys. Discuss., https://doi.org/10.5194/acp-2018-347

Manuscript under review for journal Atmos. Chem. Phys.

Discussion started: 23 April 2018

(c) Author(s) 2018. CC BY 4.0 License.
Atmospheric

Chemistry and Physics

Discussions

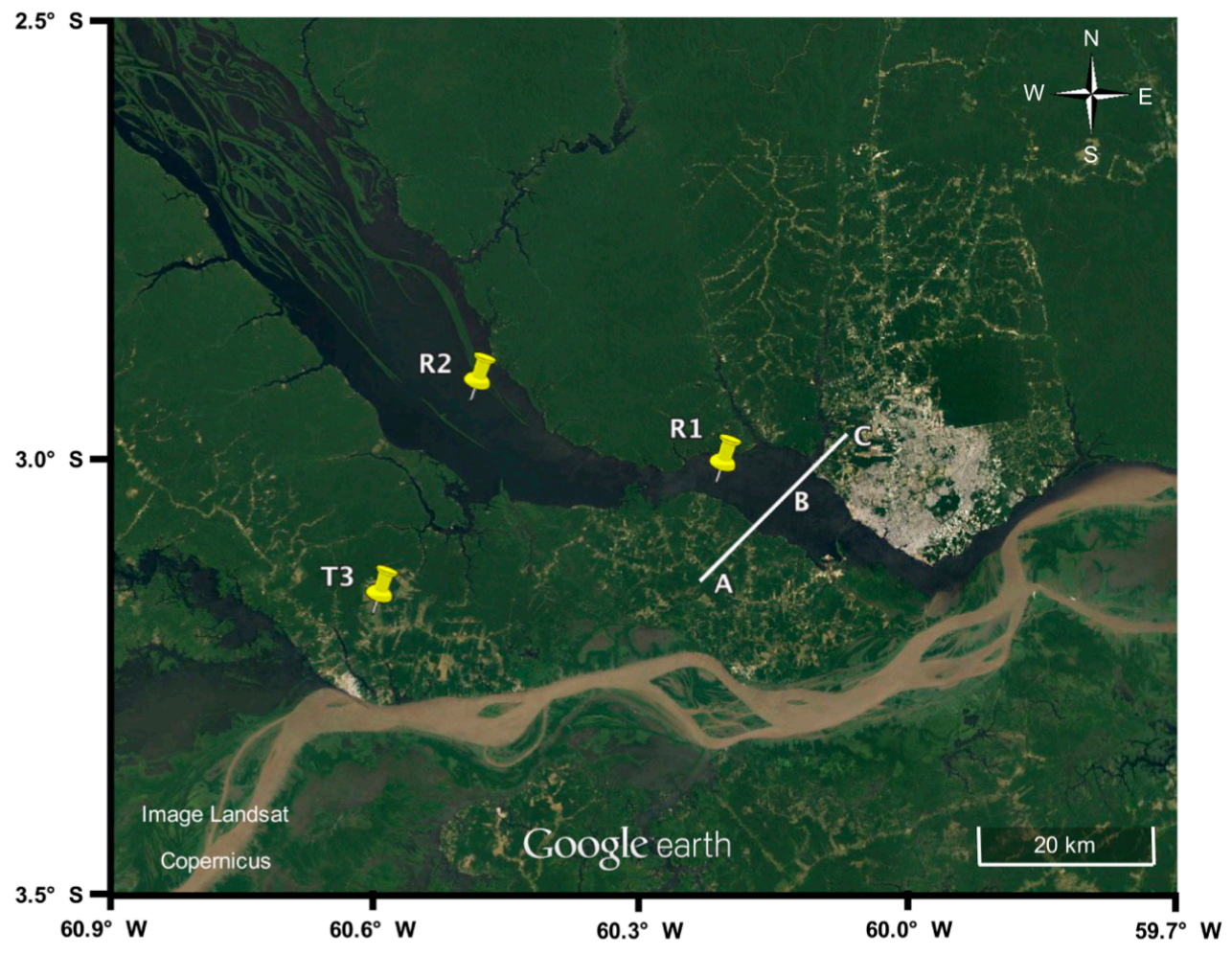

Figure 1 
Atmos. Chem. Phys. Discuss., https://doi.org/10.5194/acp-2018-347

Manuscript under review for journal Atmos. Chem. Phys.

Discussion started: 23 April 2018

(c) Author(s) 2018. CC BY 4.0 License.

(c) (1)
Atmospheric

Chemistry and Physics

Discussions
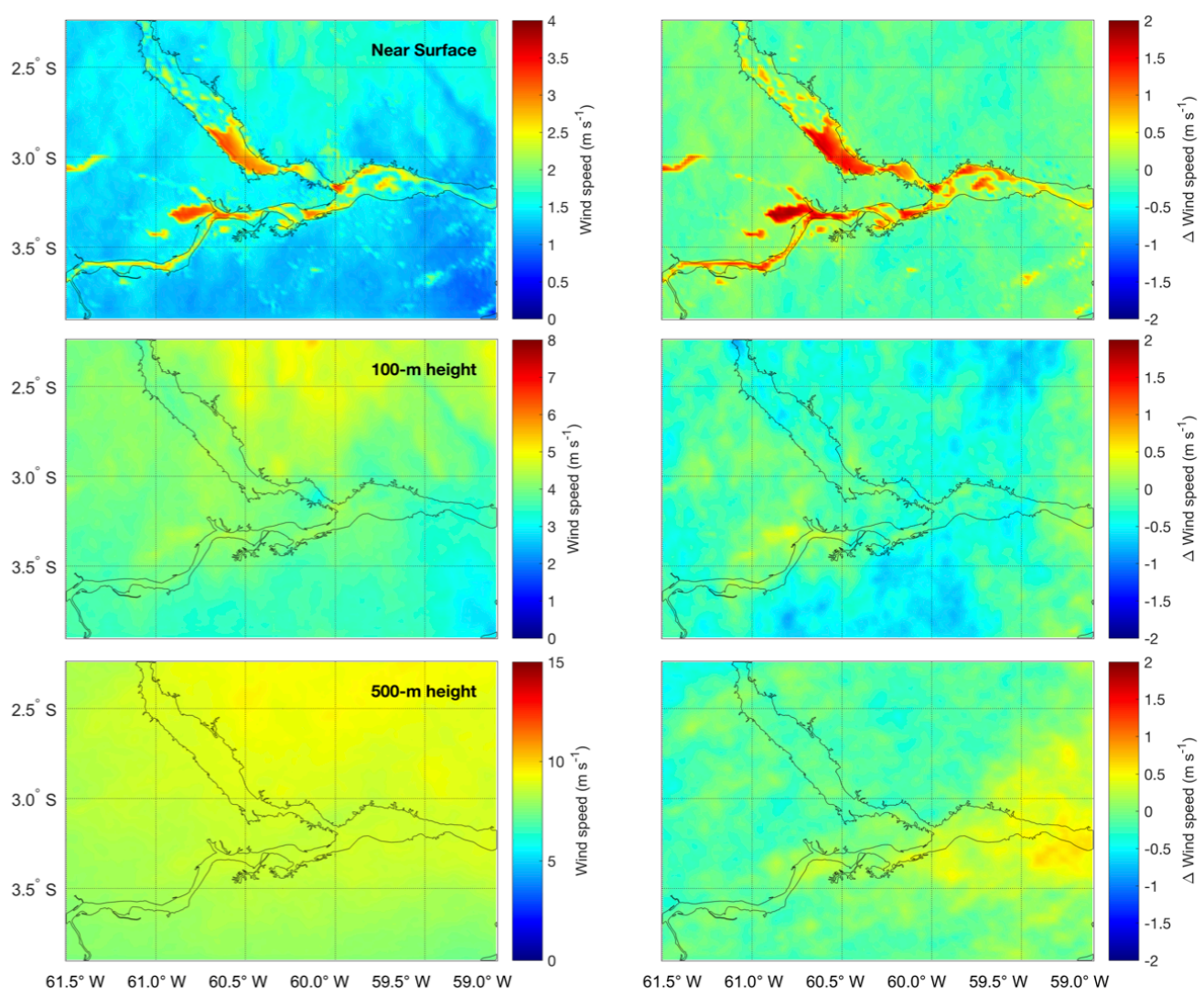

Figure 2 
Atmos. Chem. Phys. Discuss., https://doi.org/10.5194/acp-2018-347

Manuscript under review for journal Atmos. Chem. Phys.

Discussion started: 23 April 2018

(c) Author(s) 2018. CC BY 4.0 License.

(c) (1) \begin{tabular}{l} 
Atmospheric \\
Chemistry \\
and Physics \\
\hline Discussions
\end{tabular}
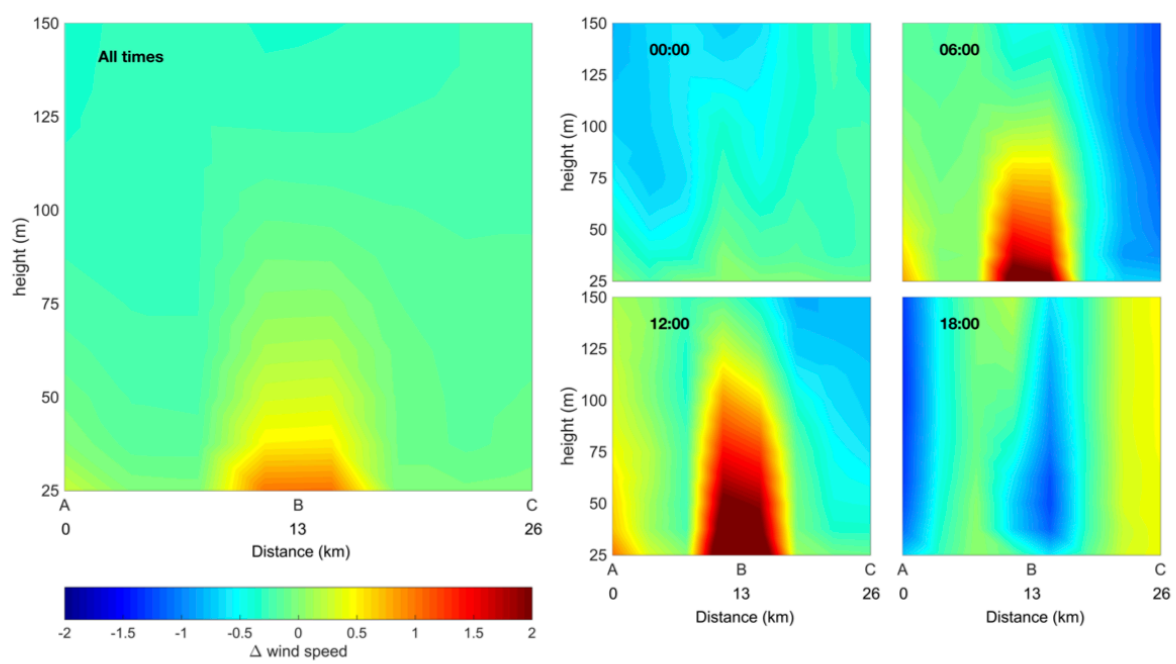

Figure 3 
Atmos. Chem. Phys. Discuss., https://doi.org/10.5194/acp-2018-347

Manuscript under review for journal Atmos. Chem. Phys.

Discussion started: 23 April 2018

(c) Author(s) 2018. CC BY 4.0 License.

(c) (1)
Atmospheric

Chemistry and Physics

Discussions
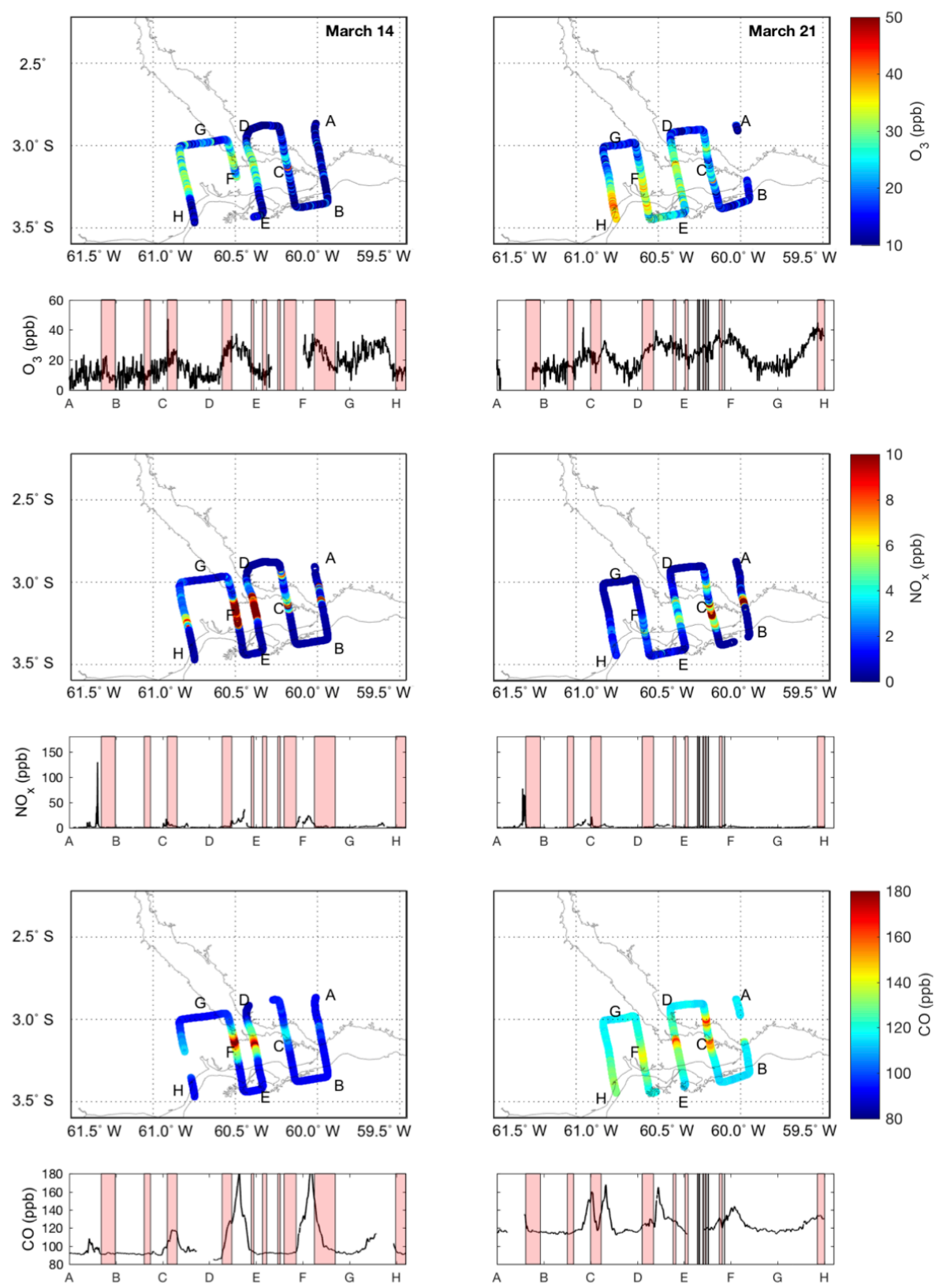

Figure 4 
Atmos. Chem. Phys. Discuss., https://doi.org/10.5194/acp-2018-347

Manuscript under review for journal Atmos. Chem. Phys.

Atmospheric

Chemistry

Discussion started: 23 April 2018

(c) Author(s) 2018. CC BY 4.0 License.
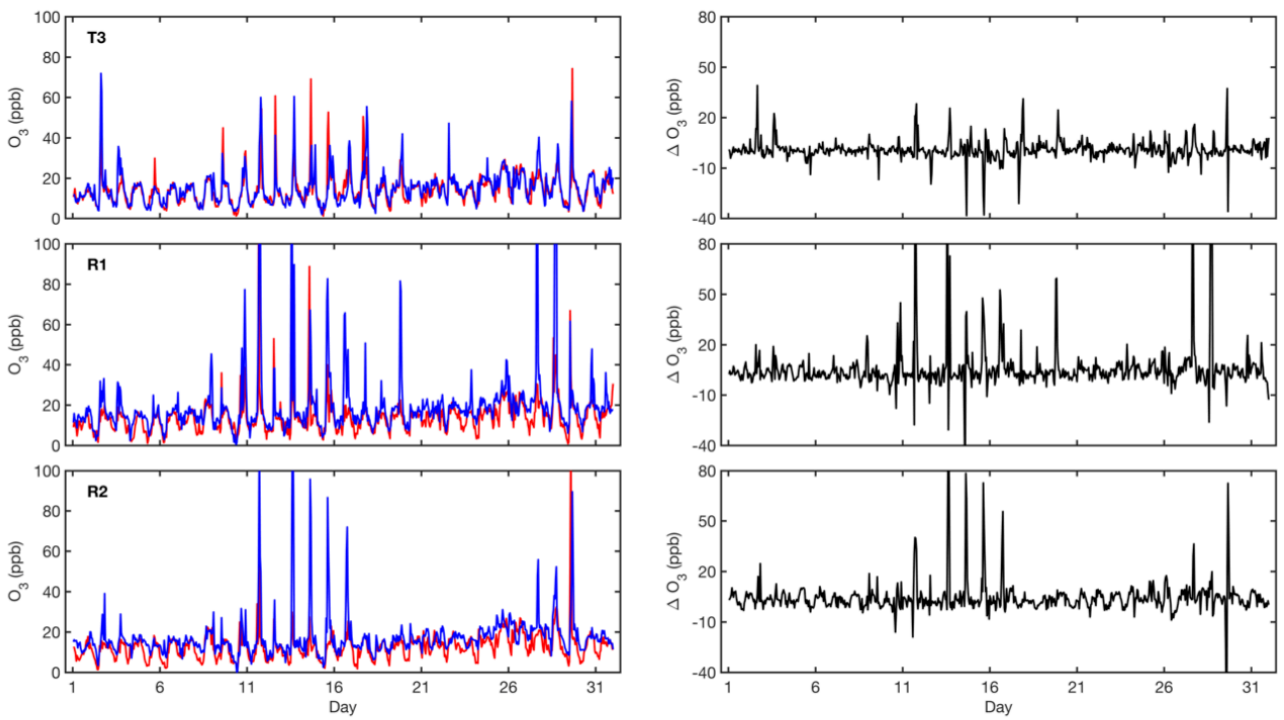

Figure 5 
Atmos. Chem. Phys. Discuss., https://doi.org/10.5194/acp-2018-347

Manuscript under review for journal Atmos. Chem. Phys.

Atmospheric

Chemistry

Discussion started: 23 April 2018

(c) Author(s) 2018. CC BY 4.0 License.
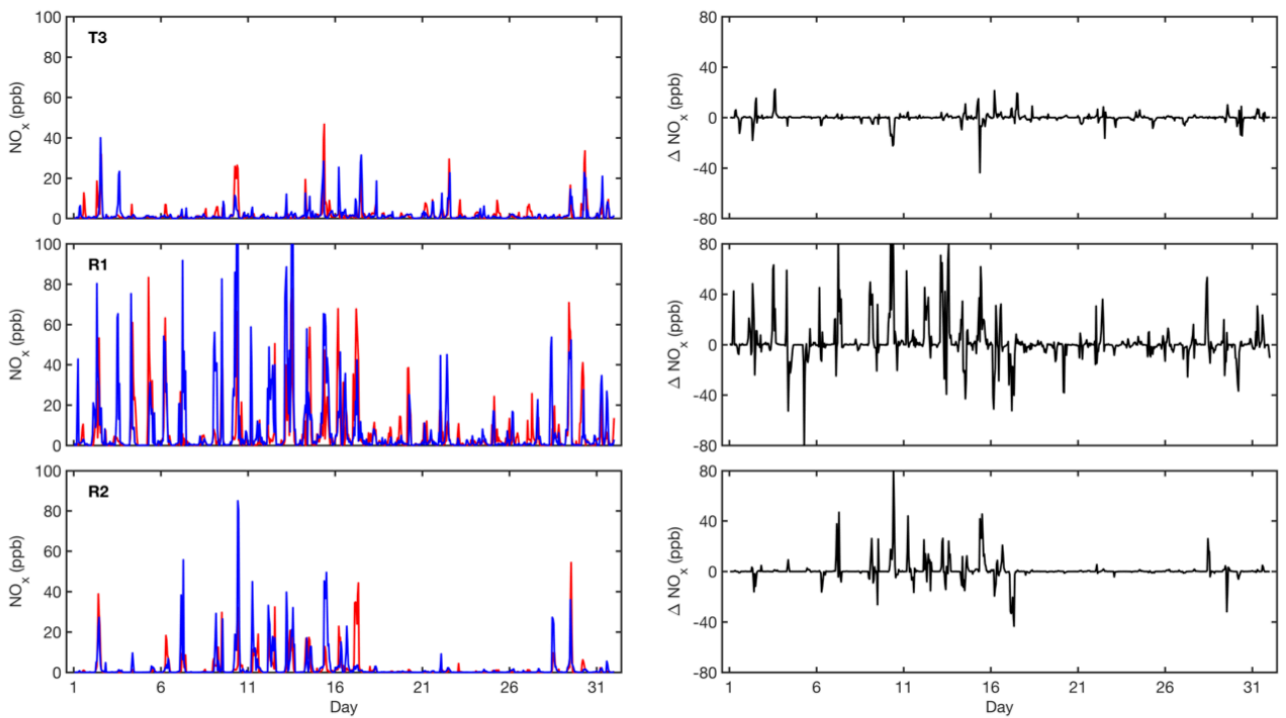

Figure 6 
Atmos. Chem. Phys. Discuss., https://doi.org/10.5194/acp-2018-347

Manuscript under review for journal Atmos. Chem. Phys.

Discussion started: 23 April 2018

(c) Author(s) 2018. CC BY 4.0 License.
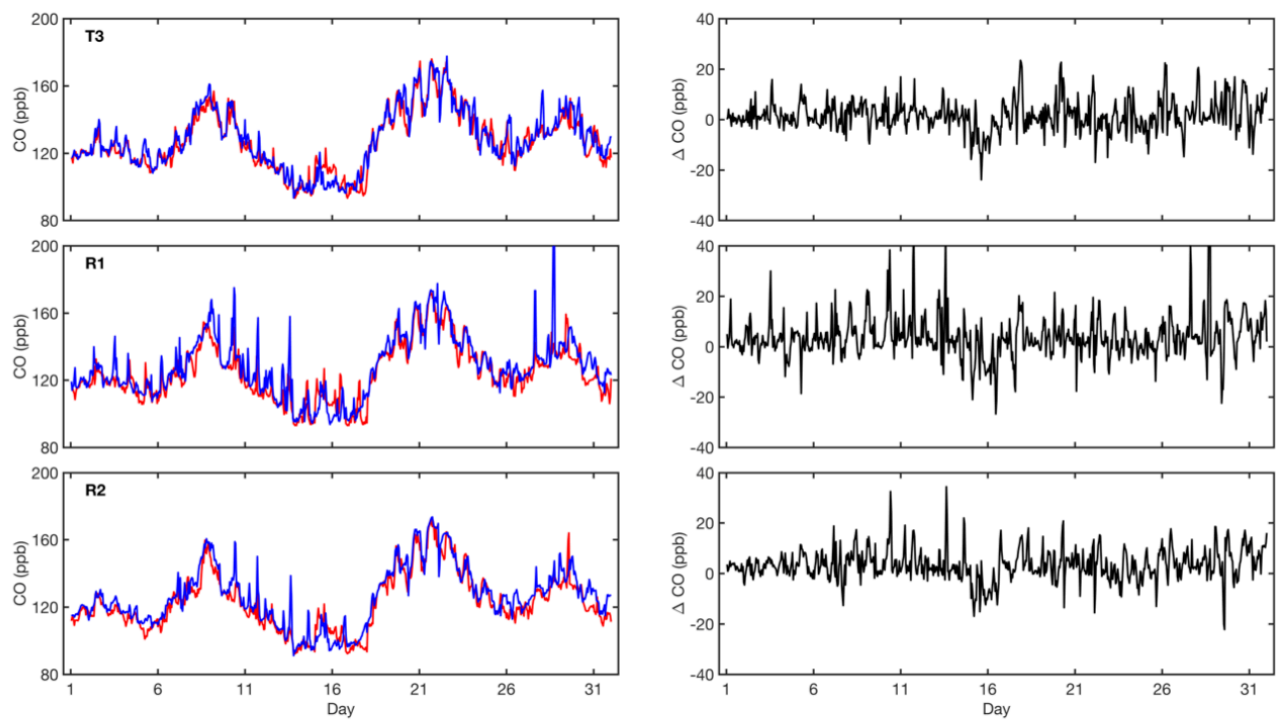

Figure 7 
Atmos. Chem. Phys. Discuss., https://doi.org/10.5194/acp-2018-347

Manuscript under review for journal Atmos. Chem. Phys.

Discussion started: 23 April 2018

(c) Author(s) 2018. CC BY 4.0 License.
Atmospheric

Chemistry and Physics

Discussions

(c) (i)

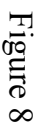
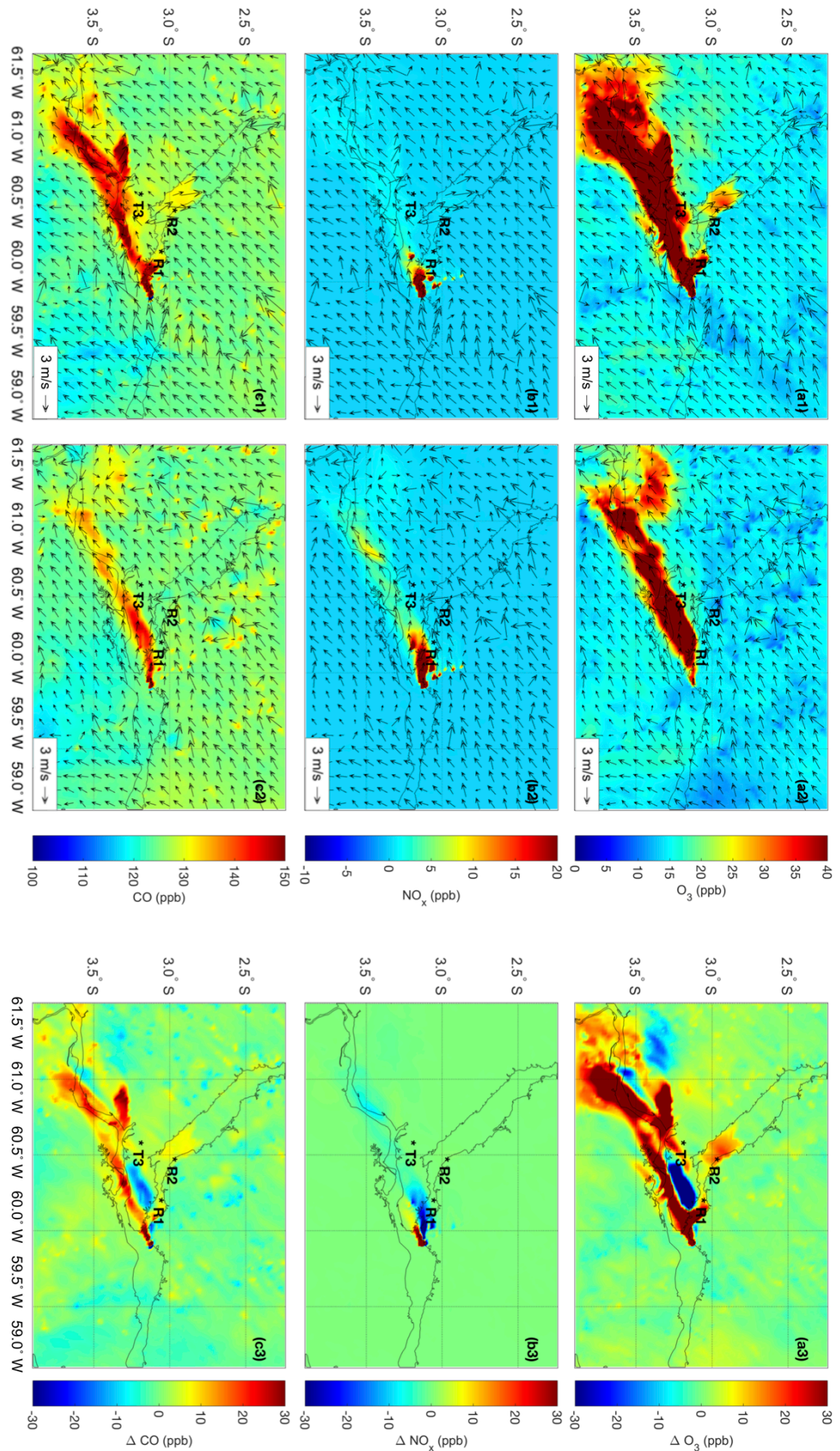